\title{
Demonstration of a solar combi-system utilizing stable supercooling of sodium acetate trihydrate for heat storage
}

\author{
Englmair, Gerald; Kong, Weiqiang; Berg, Jakob Brinkø; Furbo, Simon; Fan, Jianhua
}

Published in:

Applied Thermal Engineering

Link to article, DOI:

10.1016/j.applthermaleng.2019.114647

Publication date:

2020

Document Version

Peer reviewed version

Link back to DTU Orbit

Citation (APA):

Englmair, G., Kong, W., Berg, J. B., Furbo, S., \& Fan, J. (2020). Demonstration of a solar combi-system utilizing stable supercooling of sodium acetate trihydrate for heat storage. Applied Thermal Engineering, 166, [114647]. https://doi.org/10.1016/j.applthermaleng.2019.114647

\section{General rights}

Copyright and moral rights for the publications made accessible in the public portal are retained by the authors and/or other copyright owners and it is a condition of accessing publications that users recognise and abide by the legal requirements associated with these rights.

- Users may download and print one copy of any publication from the public portal for the purpose of private study or research.

- You may not further distribute the material or use it for any profit-making activity or commercial gain

- You may freely distribute the URL identifying the publication in the public portal 


\title{
Demonstration of a solar combi-system utilizing stable supercooling of sodium acetate trihydrate for heat storage
}

\author{
Gerald Englmair ${ }^{1,2}$, Weiqiang Kong ${ }^{1}$, Jakob Brinkø Berg ${ }^{1}$, Simon Furbo ${ }^{1}$ and Jianhua Fan ${ }^{1}$ \\ ${ }^{1}$ Department of Civil Engineering, Technical University of Denmark, Brovej 118, 2800 Kgs. Lyngby, Denmark \\ ${ }^{2}$ Sino-Danish Center, University of Chinese Academy of Sciences, 380 Huaibeizhuang, Huairou district, Beijing, China
}

\begin{abstract}
Achieving a high fraction of solar heat in heat supply for domestic buildings would reduce the use of fossil fuels for heat generation and has been a goal for a long time. Combined short and long-term heat storage has been identified as one way of achieving solar fractions higher than 50 percent in heat supply for domestic buildings. To this end, a laboratory solar heating system was built with heat-pipe tubular collectors $22.4 \mathrm{~m}^{2}$ in aperture and a heat-storage prototype consisting of a $735 \mathrm{~L}$ water tank and four PCM units each containing $200 \mathrm{~kg}$ sodium acetate trihydrate (SAT) composite. The SAT composite was utilized as sensible heat storage with the additional ability to release heat of fusion on demand. Operation was demonstrated with the space heating and hot water demand patterns of a standard-size Passive House in the Danish climate. A strategy was developed to control the system. Seven operation modes enabled combined charging of water tank and PCM units, heat transfer from PCM units to the water tank when heat was in demand, and the right timing of auxiliary heating. We present the controller settings identified and the heat transfer fluid flow rates applied. Sequences of water tank charging, and single and parallel PCM unit charging were used to match the collector power available and the heat transfer limitations of the stores. During the charging of PCM units, the flow temperature was kept between 70 and $95{ }^{\circ} \mathrm{C}$ to allow continuous heat transfer rates of up to $16 \mathrm{~kW}$. Peaks of up to $36 \mathrm{~kW}$ occurred when PCM units were added to the charging circuit. During heat transfer from PCM units to the water tank, flow temperatures were close to the SAT composite temperature and thermal power of up to $6 \mathrm{~kW}$ was measured. The heat stores were efficiently utilized in spring and autumn. The developed control strategy and measurement data from system demonstration will form the basis for numerical performance investigations.
\end{abstract}

Keywords: Solar heating system; system demonstration; control strategy; heat storage prototype; phase change material; stable supercooling. 


\section{Nomenclature}

$\begin{array}{ll}\text { Symbols } & \\ A & \text { area }\left(\mathrm{m}^{2}\right) \\ c_{p} & \text { specific heat capacity }(\mathrm{kJ} / \mathrm{kg} \mathrm{K}) \\ \mathrm{E}_{\text {aux }} & \text { electrical heater (auxiliary) } \\ G & \text { global irradiance }\left(\mathrm{W} / \mathrm{m}^{2}\right) \\ H & \text { height } \\ L & \text { latent heat }(\mathrm{kJ} / \mathrm{kg}) \\ Q & \text { thermal energy, heat }(\mathrm{kWh}) \\ \dot{Q} & \text { heat transfer rate }(\mathrm{kW}) \\ S & \text { Energy storage density }\left(\mathrm{kWh} / \mathrm{m}^{3}\right) \\ t & \text { time }(\mathrm{s}) \\ T & \text { temperature }\left({ }^{\circ} \mathrm{C}\right) \\ \varnothing & \text { diameter }(\mathrm{m}) \\ V & \text { volume }\left(\mathrm{m}^{3}\right) \\ \dot{V} & \text { volume flow rate }(\mathrm{l} / \mathrm{min})\end{array}$

\section{Greek letters}

$\begin{array}{ll}\Delta T & \text { temperature difference }(\mathrm{K}) \\ \rho & \text { density }\left(\mathrm{kg} / \mathrm{m}^{3}\right)\end{array}$

\section{Subscripts}

amb ambient

aux auxiliary

act actual storage density

B buffer heat storage (water tank)

coll collector outlet

cycle cycles per year

DHW domestic hot water

$\begin{array}{ll}\text { eff } & \text { effective storage density } \\ \text { in } & \text { inlet line } \\ \text { liquid } & \text { liquid SAT } \\ \text { max } & \text { maximum temperature } \\ \text { melting } & \text { melting temperature of PCM } \\ \text { out } & \text { outlet line } \\ \text { PCM } & \text { phase change material } \\ \text { phy } & \text { physical storage density } \\ \text { sec } & \text { secondary circuit } \\ \text { service } & \text { service } \\ \text { SH } & \text { space heating } \\ \text { solid } & \text { solidified SAT } \\ \text { total } & \text { total, on the collector plane } \\ \text { water } & \text { water }\end{array}$

\section{Abbreviations}

DHW domestic hot water

HTF heat transfer fluid

HX heat exchanger

LabVIEW laboratory virtual instrument engineering workbench

MEV membrane expansion vessel

P pump

PCM phase change material

SAT sodium acetate trihydrate

SH space heating

X control valve 


\section{Introduction}

\subsection{Solar combi-systems}

Solar heating is a promising technology for reducing fossil-fuel consumption in the building sector. Solar combisystems in various designs [1] can help cover domestic hot water and space heating demand. IEA SHC Task 26 evaluated nine solar combi-system designs on the European market [2] and found that the optimal collector tilt, which depends primarily on the latitude, also needs to increase to better utilize the solar irradiation during the heating season if the solar fraction is to be increased. Andersen [3] investigated how to design solar combi-systems that can achieve high solar fractions. Detailed investigations were conducted on storage tanks in terms of discharge from different levels [4], inlet stratifiers [5], and degrees of stratification efficiency [6]. Based on elaborated knowledge, Thür [7] developed a compact system focused on minimizing temperature to reduce heat losses and to increase the efficiency of the solar collector.

Efficient heat storage has been identified as the key component for well-performing solar heating systems [8], [9]. Long-term storage of heat is essential to cover heat demand with solar fractions larger than $50 \%$ in central and northern Europe. Water tanks have been used for this purpose [10,11], but large storage volumes were necessary to compensate for sensible heat losses.

\subsection{Combined short and long-term heat storage}

As an alternative to water, the International Energy Agency Solar Heating and Cooling Task 42/ Annex 29 [12] investigated novel materials for more efficient heat storage over long periods. Prototype heat stores have recently been developed that use solid sorption materials in an open system [13,14] or in a closed system [15,16], or that use liquid absorption with sodium-hydroxide $[17,18]$. Thermochemical long-term heat storage with a salt/zeolite composite has been demonstrated in building scale [19], [20]. Phase change materials (PCMs) have been used in low and medium temperature applications [21], especially building applications [22,23]. Salt hydrate PCMs have been considered because of their relatively high latent heat.

Quinnell and Davidson [24] have showed that the combined use of material properties, such as reaction enthalpy and sensible heat capacity, gives advantages in solar thermal systems in terms of energy supply flexibility. The combined use of latent heat of fusion and sensible heat capacity is possible with the salt hydrate sodium acetate trihydrate (SAT), which can stably supercool to ambient temperatures while preserving its heat of fusion [25], [26], [27] until crystallization is initiated.

When a PCM is in the liquid, supercooled state and in thermal equilibrium to its surroundings, it can in principle store heat loss-free. After melting and heating SAT in a closed container with smooth inner surfaces to a temperature above $77^{\circ} \mathrm{C}$ and by avoiding pressure changes in the container, sensible heat can be discharged until room temperature is reached [28]. Then, the crystallization of the supercooled solution can be initiated by seed crystal injection [29,30] or by local cooling [31], and the heat of fusion will be released as it crystalizes. This heat storage concept dates back to initial research in the late 1920s [32] and was later found to enable more efficient solar heat supply of low-energy buildings in summer and transitional seasons [33]. 


\subsection{Heat storage prototypes utilizing stable supercooling of SAT}

SAT is attractive for combined short and long-term heat storage due to its relatively high specific heat capacities in liquid and solid phases [29] in combination with its heat of fusion $\left(264 \mathrm{~kJ} / \mathrm{kg}\right.$ [34]). Its melting point of $58{ }^{\circ} \mathrm{C}$, the low price for industrial use (typically below 0.5 Euros per kilogram in large quantities) and its non-toxic properties are appropriate for heat supply in buildings. Its density has been determined to be $1.27 \mathrm{~kg} / \mathrm{L}$ at $90^{\circ} \mathrm{C}$ in liquid state and 1.33 to $1.34 \mathrm{~kg} / \mathrm{L}$ in an open sample after solidification from supercooled state [35].

To overcome phase separation of SAT in supercooled state [36], SAT composites were developed in previous research at the Technical University of Denmark. Promising composites contained extra water, carboxymethyl cellulose and xanthan rubber, as well as ethylenediamnietetraacetic acid and liquid polymeric solutions. When their crystallization is initiated in supercooled state at $20^{\circ} \mathrm{C}$, heat contents above $200 \mathrm{~kJ} / \mathrm{kg}$ have been measured [37]. In contact with steel, supercooled SAT composites crystallize below $-15^{\circ} \mathrm{C}$ [31]. A thermal conductivity in the range of $0.5-0.65 \mathrm{~W} / \mathrm{mK}$ has been found for solid composites containing carboxymethyl cellulose and xanthan rubber [38]. As for most PCMs, this is considered as a limitation of heat transfer.

Dannemand et al. addressed the engineering challenges of volumetric change and decreasing conductivity during SAT composite solidification by using flat [28] and cylindrical [39] prototype heat storage units. SAT has also been used in the mantle of hot water tanks [40].

Englmair et al. [41] report the design and the functionality of a heat storage prototype consisting of four flat units containing $200 \mathrm{~kg}$ SAT composites each and a $735 \mathrm{~L}$ water tank. Stable supercooling was achieved in three out of the four units. The full charge of a single unit from ambient temperature was measured at $27.4 \mathrm{kWh} .14 \mathrm{kWh}$ of sensible heat and $10.2 \mathrm{kWh}$ ( $80 \%$ heat of fusion) of heat during solidification were discharged with PCM temperatures higher than $50{ }^{\circ} \mathrm{C}$. Prototype devices for seed crystal injection worked during initial tests, but were later dismounted, due to deformation by temperature changes.

\subsection{Scope}

A novel solar combi-system with application of a previously developed heat storage prototype utilizing stable supercooling of SAT composite is presented. System tests with an array of evacuated tubular collectors and space-heating and domestic hot water patterns of a standard-size Passive House in the Danish climate were conducted to provide the following outcome:

- A control strategy with operation modes for storage charge and discharge as well as auxiliary heating

- Automated system operation by determination of threshold values for modes, settings of control valves, and optimized heat transfer fluid flow rates

- Validation of control parameter settings by system demonstration

- Analysis of the system behaviour to elucidate how water tank and PCM units can be operated for the efficient utilization of solar collectors in a single-family household.

The generated experimental data will be the basis for further system development by numerical performance investigations. The demonstration of a solar combi-system utilizing stable supercooling of SAT has not been reported before and will provide reference for more efficient solar heating by combined short and long-term heat storage. 


\section{System design}

\subsection{Components}

A system demonstrator was built in the prototype test facility at the Technical University of Denmark (northern latitude: $55.8^{\circ}$ ) to apply the domestic hot water (DHW) and space heating ( $\mathrm{SH}$ ) demand patterns. It was designed as a solar combi-system with a solar collector array, a water heat storage, and a segmented PCM heat storage utilizing SAT (Fig. 1 a).

The collector array was formed with 7 panels (totalling $22.4 \mathrm{~m}^{2}$ of aperture area) of heat pipe evacuated tubular collectors, type Thermomax HP 450 from Kingspan Renewables. They were chosen due to their relatively low heat loss coefficients (Table 1), which allow good performance during melting of SAT with collector outlet temperatures above 70 ${ }^{\circ} \mathrm{C}$. The collectors were mounted with an inclination of $45^{\circ}$ and an azimuth angle of $12^{\circ}$ towards east. Tyfocor LS, a heat transfer fluid (HTF) based on propylene glycol and water, was used to ensure frost protection. The panels were connected in 2 parallel circuits, one circuit with 4 panels and one with 3 panels in series.

The water tank (Fig. 1 b) had a volume of 735 L. It was designed as tank-in-tank heat storage with an electrical resistor $\left(E_{\text {aux }}\right)$ for auxiliary heating situated at a height of $0.5 \mathrm{~m}$. The outer tank $(\varnothing: 0.8 \mathrm{~m})$ had a height of $1.6 \mathrm{~m}$ and was insulated with $0.05 \mathrm{~m}$ of mineral wool. The inner tank $(\varnothing: 0.45 \mathrm{~m}, \mathrm{~V}: 175 \mathrm{~L})$, was situated in the top-centre of the outer tank. It covered a height of $1.1 \mathrm{~m}$ and included a pipe $(\varnothing: 0.16 \mathrm{~m})$ to the bottom of the outer tank. Cold water entered the inner tank from the bottom and DHW was tapped from the top of it. The outer tank contained water as HTF. The SH circuit was connected with an outlet at a height of $1 \mathrm{~m}$ and an inlet at the bottom of the outer tank. The charging circuit was implemented with an outlet at the bottom of the outer tank, where there was also a polymeric inlet stratifier [42] to enable good thermal stratification.

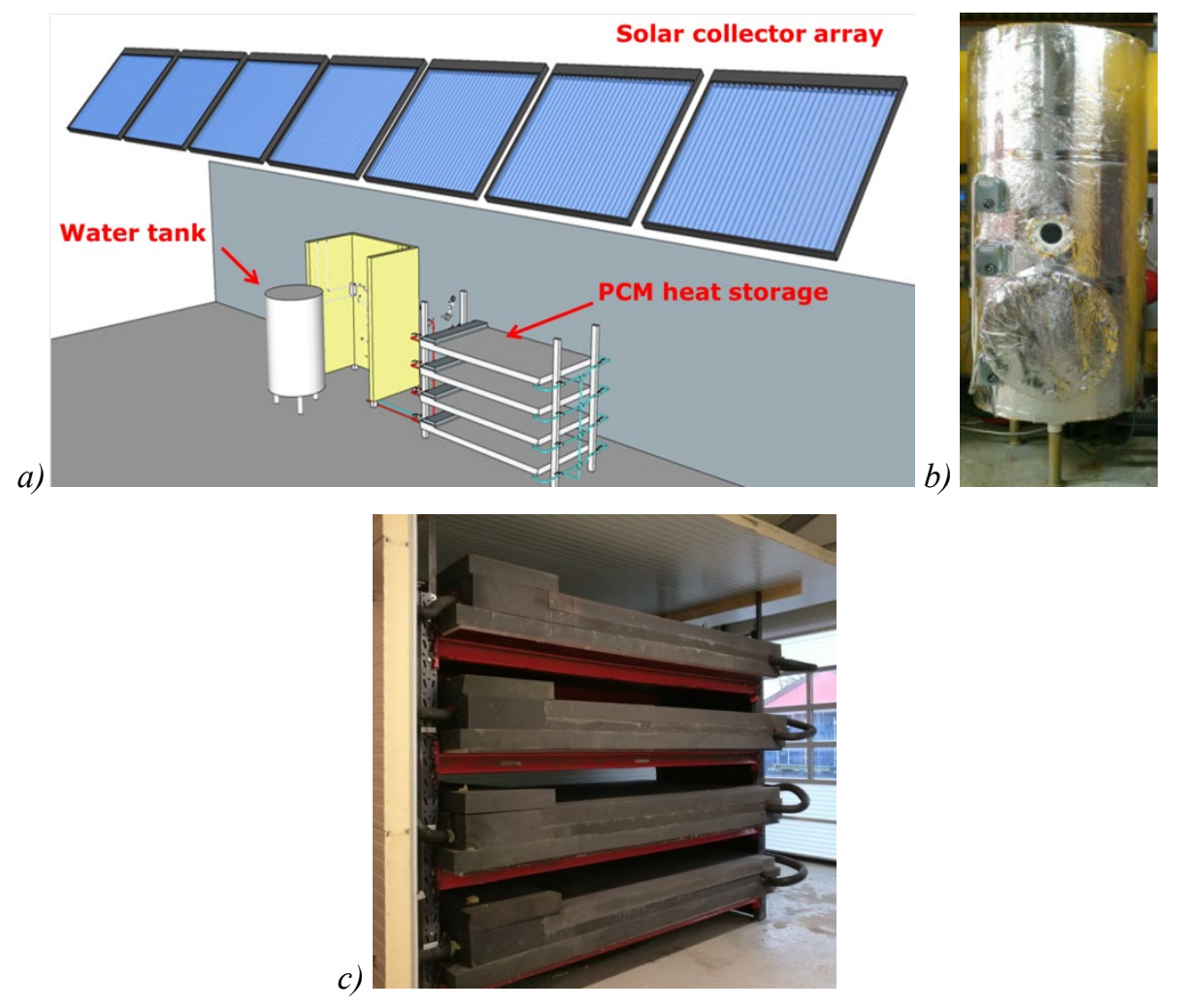

Fig.1. System demonstrator: a) Component configuration; b) Water tank; c) PCM heat storage. 
The segmented PCM heat storage (Fig. 1 c) consisted of four flat units, each containing $150 \mathrm{~L}$ of SAT composite. They were insulated with $10 \mathrm{~cm}$ of foam insulation. The hydraulic configuration, activation devices applied and the functionality of the heat storage prototype have all been previously reported [41].

The interplay of the collector array, a variable number of PCM units, and the water tank was enabled by hydraulic circuits (Fig. 3). For the collector circuit, $35 \mathrm{~m}$ of copper piping (outer $\varnothing: 20 \mathrm{~mm}$, insulation: $19 \mathrm{~mm}$ ) was installed. Circuits with a length of $9 \mathrm{~m}$ for water tank charging and $19 \mathrm{~m}$ for heat transfer to/from the PCM heat storage were realized with steel piping $(3 / 4 "$, insulation: $19 \mathrm{~mm})$. A plate heat exchanger $(\mathrm{HX})$ connected the collector circuit with pipework for storage charging. Its overall heat exchange capacity rate was calculated to be $1.100 \mathrm{~W} / \mathrm{K}$.

Table 1. Data from collector panel certification [43].

\begin{tabular}{|c|c|c|c|c|c|}
\hline $\begin{array}{c}\text { Aperture } \\
\text { area } \\
\left(\mathbf{m}^{2}\right)\end{array}$ & $\begin{array}{c}\text { Gross area } \\
\left(\mathbf{m}^{2}\right)\end{array}$ & $\begin{array}{c}\text { Peak collector } \\
\text { efficiency }(-)\end{array}$ & $\begin{array}{c}\mathbf{1}^{\text {st }} \text { order loss } \\
\text { coefficient } \\
\left(\mathbf{W} / \mathbf{m}^{2} \mathbf{K}\right)\end{array}$ & $\begin{array}{c}\mathbf{2}^{\text {nd }} \text { order loss } \\
\text { coefficient } \\
\left(\mathbf{W} / \mathbf{m}^{2} \mathbf{K}^{2}\right)\end{array}$ & $\begin{array}{c}\text { Effective heat } \\
\text { capacity } \\
\left(\mathbf{k J} / \mathbf{m}^{2} \mathbf{K}\right)\end{array}$ \\
\hline 3.2 & 4.15 & 0.750 & 1.18 & 0.010 & 4.4 \\
\hline
\end{tabular}

\subsection{Energy storage density}

For domestic heat storage, the heat capacity of the SAT applied is limited by the room temperature $\left(T_{a m b}=25^{\circ} \mathrm{C}\right)$ and the maximum HTF temperature $\left(T_{\max }=90^{\circ} \mathrm{C}\right)$. The physical storage density $\left(S_{\text {phy }}\right)$ was calculated as follows:

$\left.S_{\text {phy }}=\left[\left(T_{\text {melting }}-T_{\text {amb }}\right) * c_{p, \text { solid }}+L+\left(T_{\text {max }}-T_{\text {melting }}\right) * c_{\text {p,liquid }}\right)\right] * \rho_{\text {liquid }} \div 3.6=151 \frac{\mathrm{kWh}}{\mathrm{m}^{3}}$

where the specific heat capacities $\left(c_{p}\right)$ of SAT in liquid phase $\left(3 \mathrm{~kJ} / \mathrm{kgK}\right.$ at $\left.74{ }^{\circ} \mathrm{C}\right)$ and solid phase $\left(2.1 \mathrm{~kJ} / \mathrm{kgK}\right.$ at $\left.42{ }^{\circ} \mathrm{C}\right)$ [28] and a latent heat of fusion $(L)$ of $264 \mathrm{~kJ} / \mathrm{kg}$ [34] were applied. The density $(\rho)$ of SAT in liquid phase is lower than in solid phase and must be therefore used. A minimum density of $1.27 \mathrm{~kg} / \mathrm{L}$ at $90{ }^{\circ} \mathrm{C}$ [35] was considered.
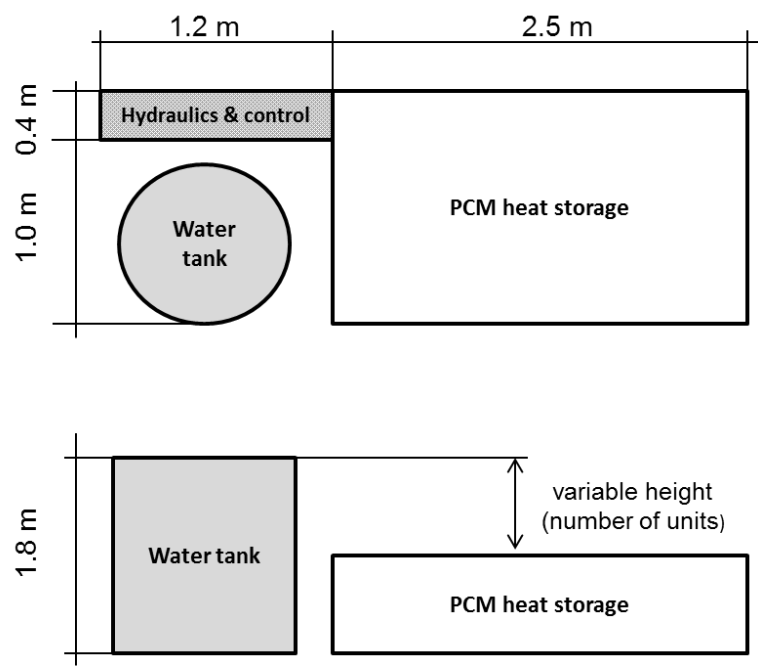

Fig. 2. Dimensions of the heat storage components.

In discharge tests, a minimum SAT temperature of $50{ }^{\circ} \mathrm{C}$ was found to be necessary for heat supply. For a single unit, a heat capacity $\left(Q_{P C M}\right)$ of $24.2 \mathrm{kWh}(14 \mathrm{kWh}$ short-term; $10.2 \mathrm{kWh}$ long-term) was measured under application 
conditions. The minimal space demand for the heat stores, hydraulic installations, and monitoring equipment is illustrated in Fig. 2. Instead of the individual insulation of PCM units in the storage prototype, several PCM units could be installed within one insulation layer. The given water tank height $(H)$ allows space for up to 14 PCM units. Including hydraulics and control, an area $\left(A_{P C M}\right)$ of $3.89 \mathrm{~m}^{2}$ would be necessary. The effective storage density $\left(S_{\text {eff }}\right)$, related to the necessary installation space of PCM units, would be:

$$
S_{e f f}=\frac{Q_{P C M^{* 14}}}{A_{P C M^{* H}}}=48 \frac{\mathrm{kWh}}{\mathrm{m}^{3}}
$$

of which $28 \mathrm{kWh} / \mathrm{m}^{3}$ are available as sensible heat storage, and $20 \mathrm{kWh} / \mathrm{m}^{3}$ can be used for long-term heat storage.

For the solar heating system, a water tank was also applied. Its storage capacity $\left(Q_{\text {water }}\right)$ was calculated to be $38 \mathrm{kWh}$, assuming an average water temperature increase of $45 \mathrm{~K}$. For maintenance access, a distance of $0.5 \mathrm{~m}$ from at least two sides was necessary. The occupied area $\left(A_{\text {service }}\right)$ was $8 \mathrm{~m}^{2}$, which corresponds to a volume demand of $14.4 \mathrm{~m}^{3}$. The actual storage density $\left(S_{a c t}\right)$ of the heat storage configuration with 4 PCM units was:

$$
S_{\text {act }}=\frac{Q_{P C M} * 4+Q_{\text {water }}}{A_{\text {service }} * H}=9.4 \frac{\mathrm{kWh}}{\mathrm{m}^{3}}
$$

With 14 PCM units installed, the actual storage density would be $26.2 \mathrm{kWh} / \mathrm{m}^{3}$.

\subsection{Potential advantages}

Space heating and domestic hot water supply is realised via the water tank (Fig. 3). Thus, thermal power requirements of household services are fulfilled with allowing heat transfer from the collector array and the PCM heat storage units with low HTF flow rates and restricted thermal power. An auxiliary heater in the water tank ensures SH and DHW supply with required HTF temperatures. Functionality tests [41] showed that: a) PCM units were charged with thermal power up to $16 \mathrm{~kW}$ in parallel; b) Typical discharge power of PCM units was in the range of 4-16 kW with SAT in liquid state and in the range of 2-4 kW during SAT solidification; c) HTF temperatures during continuous discharging of flat PCM units without and with solidification were sufficiently high to cover SH demands; d) For hot water supply (temperatures above $45^{\circ} \mathrm{C}$ ) pulsed-flow was required during discharging of PCM units with SAT solidification. This means that the presented system could be applied similar to solar combi-systems without PCM heat storage.

The experimental findings described in this paper were used to simulate an optimized system with five PCM units, containing $200 \mathrm{~L}$ of SAT composite each, and a $0.6 \mathrm{~m}^{3}$ water tank for heat storage in an energy-efficient house located in Denmark [44]. Results showed that hot water and space heating, with a yearly total energy demand of $4000 \mathrm{kWh}$, could be covered with a solar fraction of approximately $70 \%$. Due to the long-term heat storage property of the PCM heat store, power-to-heat conversion could be possible with wind energy in winter. In this way, almost all heat demand could be covered by solar and wind energy - even with a relatively small storage volume. In this context, the PCM heat storage provides two benefits: a) On-demand utilization of heat of fusion in periods without sunshine; b) An effective PCM heat storage density of $48 \mathrm{kWh} / \mathrm{m}^{3}$. Without PCM storage, the available installation space could be used for two cylindrical tanks containing water volumes of $1 \mathrm{~m}^{3}$ (height: $2 \mathrm{~m}$, diameter: $0.8 \mathrm{~m}$ ) each and $0.15 \mathrm{~m}$ insulation to minimize sensible heat losses. This water tank size would be appropriate for building-integrated buffer heat storage, considering room height and installation needs. Assuming an average water-temperature increase of $45 \mathrm{~K}$ an effective heat storage density of 25 $\mathrm{kWh} / \mathrm{m}^{3}$ would result, which is about half the value of a PCM heat storage with multiple units.

Rathgeber et al. [45] calculated that the maximum acceptable storage capacity costs of heat stores in buildings range 
from $18 € / \mathrm{kWh}$ for monthly utilization to $70 € / \mathrm{kWh}$ for weekly utilization of the stores. The price of water heat stores in solar combi-systems is typically above $50 € / \mathrm{kWh}$ storage capacity, highly dependent on the storage size, the installed heat exchangers and the quality of the thermal insulation [46]. Market prices for industrial SAT are below $0.5 € / \mathrm{kg}$ and for additives like carboxymethyl cellulose and xanthan rubber below $4 € / \mathrm{kg}$. $5.5 \mathrm{~kg}$ SAT and less than $0.2 \mathrm{~kg}$ of additives are needed for one $\mathrm{kWh}$ of heat storage capacity. Consequently, SAT composite prices would contribute about $3 € / \mathrm{kWh}$ to specific storage capacity costs. PCM units can be manufactured in steel utilizing small local cooling devices for ondemand crystallization of SAT composites [31]. Thus, it can be expected that optimized PCM units utilizing stable supercooling of SAT composites instead of water tanks would not significantly raise costs of systems designed for high solar fractions of heat supply.

\section{Experimental method}

\subsection{Monitoring and control}

System operation was realized by a LabVIEW-based data acquisition and control program. The LabVIEW program was executed on a National Instruments Compact Rio 9085 industrial computer running a real-time operating system. Thermocouples and thermopiles were connected to a 16-channel thermocouple data acquisition module (NI9214). Flow meter signals were read via a 32-channel digital input/output data acquisition module (NI9403). Uncertainties resulted mainly from the sensors installed (Table 2). Pump speed and valve positions (X) were set by the Compact Rio computer to operate hydraulic circuits (Fig. 3). A digital output module (NI 9476) was used to control valve motors (Honeywell, $\mathrm{V} 4043 \mathrm{H}$ ) and auxiliary heating. An analogue output module (NI 9263) and a digital output module (NI 9403) were used for HTF flow rate control via pump speed. An operator monitor program, also programmed in LabVIEW, was created to enable operators to monitor the system and operate it manually from an adjacent PC. To estimate SH requirements, outdoor sensors were positioned to gather information about solar radiation levels $\left(G_{\text {total }}\right)$ and ambient temperature $\left(T_{a m b}\right)$.

Table 2. Measurement devices installed.

\begin{tabular}{|c|c|c|}
\hline Measurement device & Type & Uncertainty \\
\hline $\begin{array}{l}\text { Thermocouple }\left(T_{B i}, T_{\text {coll }}, T_{D H W_{-} i n}, T_{D H W_{-} o u t}, T_{H X_{-} \text {out }},\right. \\
\left.T_{P C M i}, T_{S H_{-} i n}, T_{S H_{-} \text {out }}\right)\end{array}$ & TT-type (copper/ constantan) & $0.5 \mathrm{~K}[47]$ \\
\hline $\begin{array}{l}\text { Thermopile with two integrated TT-type } \\
\text { thermocouples }\left(\Delta T_{\text {coll }}, \Delta T_{P C M}, \Delta T_{\text {sec }}\right)\end{array}$ & $\begin{array}{l}\text { 5-junction thermopile with TT-type } \\
\text { thermocouples }\end{array}$ & $0.1 \mathrm{~K}[47]$ \\
\hline Flow meters $\left(\dot{V}_{\text {coll }}, \dot{V}_{D H W}, \dot{V}_{P C M}, \dot{V}_{S H}, \dot{V}_{\text {sec }}\right)$ & Class 2 & $\begin{array}{c}2 \% \text { of reading } \\
\text { (in accordance with EN 1434)* }\end{array}$ \\
\hline Pyranometer $\left(G_{\text {total }}\right)$ & Kipp \& Zonen CM3 & $\begin{array}{c}15 \mathrm{~W} / \mathrm{m}^{2} \\
\text { (below } 200 \mathrm{~W} / \mathrm{m}^{2} \text { ) }\end{array}$ \\
\hline
\end{tabular}

"The accuracy range was experimentally proved for the flow rate range applied before installation.

Heat losses from the hydraulic circuit to the PCM storage were evaluated between thermopiles at the heat exchanger $\left(\triangle T_{s e c}\right)$ and at the PCM heat storage $\left(\triangle T_{P C M}\right)$. Heat losses during water tank charging were calculated based on measured pipework length. 


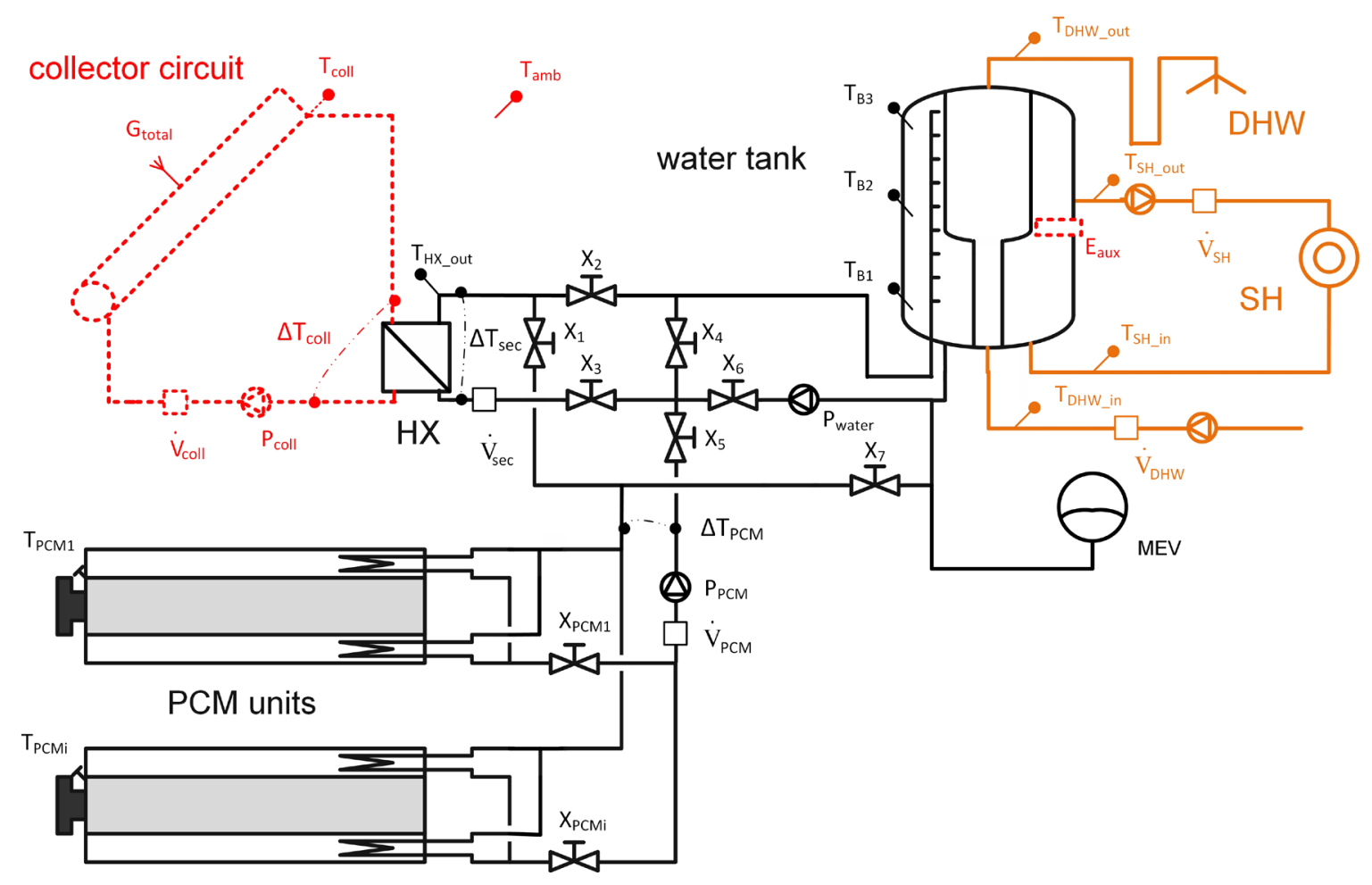

Fig. 3. System layout with heat storage components in black, heat sources in red (dashed line), and heat sinks in orange.

\subsection{Hot water and space heating demand}

Characteristic SH patterns were found in a previously conducted simulation of a $130 \mathrm{~m}^{2}$ building built to Passive House Standard [48] and using the Danish weather reference year. The annual SH demand was $15 \mathrm{kWh} / \mathrm{m}^{2}$. The building model included south-orientated windows. When the hourly average global irradiance $(G)$ was above $200 \mathrm{~W} / \mathrm{m}^{2}$, there were no heating loads in the simulation. Hourly heating loads, depending on $G$ and ambient temperature $\left(T_{a m b}\right)$, were fitted with Equations 4-7:

$$
\begin{array}{ll}
0 \mathrm{~W} / \mathrm{m}^{2}<G<10 \mathrm{~W} / \mathrm{m}^{2}: & \dot{Q}_{S H}=-0.0526 * T_{a m b}+0.7764[\mathrm{~kW}] \\
10 \mathrm{~W} / \mathrm{m}^{2}<G<50 \mathrm{~W} / \mathrm{m}^{2}: & \dot{Q}_{S H}=-0.0538 * T_{a m b}+0.7196[\mathrm{~kW}] \\
50 \mathrm{~W} / \mathrm{m}^{2}<G<100 \mathrm{~W} / \mathrm{m}^{2}: & \dot{Q}_{S H}=-0.0503 * T_{a m b}+0.5458[\mathrm{~kW}] \\
100 \mathrm{~W} / \mathrm{m}^{2}<G<200 \mathrm{~W} / \mathrm{m}^{2}: & \dot{Q}_{S H}=-0.0328 * T_{a m b}+0.2761[\mathrm{~kW}]
\end{array}
$$

Heat-draw for space heating was enabled in intervals of 6 hours (Fig. 9, Fig. 10). In this way, it was possible to calculate heat demand for 6 hours based on measurements from the monitoring system. SH was enabled from $15^{\text {th }}$ October to $31^{\text {st }}$ March and used data collected from outdoor sensors as previously described.

The Danish code of practice for domestic water supply DS 439 [49] recommends a daily DHW consumption of 4.36 $\mathrm{kWh}$ in a standard house with 3.5 occupants and a cold water temperature of $10^{\circ} \mathrm{C}$. This consumption does not include hot water for kitchen-use. For system demonstration, the DHW consumption was calculated with 113L of hot water at 45 ${ }^{\circ} \mathrm{C}$ daily, considering the comfort requirements of all users and efficient use of water. This results in daily loads of 4.6 $\mathrm{kWh}$. Three hot water draw-offs a day $(7: 00 \mathrm{~h}, 12: 00 \mathrm{~h}, 19: 00 \mathrm{~h})$, with $1.53 \mathrm{kWh}$ of heat each draw-off, were applied to simulate user behaviour (Fig. 9, Fig. 10). 


\subsection{Demonstration}

To match supply from solar collectors and heat demands in an efficient way, a control strategy with modes for charging and discharging the heat storage prototype was applied. Threshold conditions for operation modes and subroutines for PCM discharge were tested until the system was able to operate automatically. Valve settings, optimized HTF flow rate, and temperature settings were identified by manual parameter control in the LabVIEW operator monitoring and control program.

The resulting system behaviour was studied during automated operation from February 2016 until April 2017. From $30^{\text {th }}$ of June until $21^{\text {st }}$ September 2016, the collector array was covered to avoid stagnation conditions. Utilization of SAT crystallization from stable supercooled state was demonstrated with manual system settings. This was necessary because of limitations in the activation devices [41].

The setting of operation modes, heat transfer rates to the water tank and the PCM heat storage, and the state of PCM units were analysed with data from two characteristic periods. The applicability of combined charging of water tank and PCM units and the necessary subroutines during PCM storage charging was evaluated for a spring day with clear sky. Measurements and operation mode settings were logged in 10 second intervals. Data analysis was based on averaged values for 1 minute and 1 hour. Heat transfer rates in the circuits were calculated using Equation 8:

$$
\dot{Q}=\dot{V}_{i} \cdot c_{p} \cdot \rho \cdot \Delta T_{\text {in }- \text { out }}
$$

where $\dot{V}_{i}$ is the measured volume flow rate of the HTF, $c_{p}$ is the specific heat capacity of the HTF at mean temperature between $T_{\text {in }}$ and $T_{\text {out }}$, and $\rho$ is the density of the heat transfer fluid at $T_{\text {out }}$ where the volume flow rates were measured. $\Delta T$ was measured by thermopiles.

DHW-tapping and SH-draw were realized using two cooling circuits at the prototype test facility (Fig. 3). HTF flow started at set times and stopped when previously set heat demands were measured:

$$
Q_{i}=\int\left(\dot{V}_{i} \cdot c_{p} \cdot \rho \cdot\left(T_{i, \text { in }}-T_{i, \text { out }}\right)\right) \cdot d t
$$

where $\dot{V}_{i}$ was the measured volume flow rate of the HTF at either $\dot{V}_{D H W}$ or $\dot{V}_{S H}$. The temperature differences were calculated between $T_{D H W_{-} \text {in }}$ and $T_{D H_{-} \text {out }}$, and between $T_{S_{-} \text {in }}$ and $T_{S H_{-} \text {out }}$. HTF properties were determined in accordance with Equation 8.

\section{Experimental results and discussion}

\subsection{Control strategy}

An overview of the concept is presented in Fig. 4, where operation modes are shown in black boxes, external condition are shown in boxes with dotted frame and resulting settings in boxes with dashed frame. Mode A defines states without collector circuit operation when the water tank charge is sufficient for DHW and SH demand. In this mode, the control system is in standby, with just monitoring system measurements being taken. The collector circuit starts operating when measurements fulfil threshold conditions, and there are three different modes (B-D) of using its thermal power for storage charging. The water tank has first priority in order to cover DHW and SH demands. Additional solar yield is 
stored in the PCM. An additional subroutine for charging individual units of the PCM heat storage was found useful during functionality tests [41]. When all PCM units are fully charged, the water tank is charged until the thermal power of the collector circuit can no longer be transferred and the collector circuit returns to standby. There are three other operating modes $(\mathrm{E}-\mathrm{G})$ that are triggered by demand when the collector circuit is in standby and the water tank is insufficiently charged. Discharge of sensible heat from all PCM units has priority to minimize heat losses. SAT crystallization, followed by discharge of stored heat of fusion, is then initialized unit by unit. Auxiliary heating of the water tank takes place when all stores have discharged.

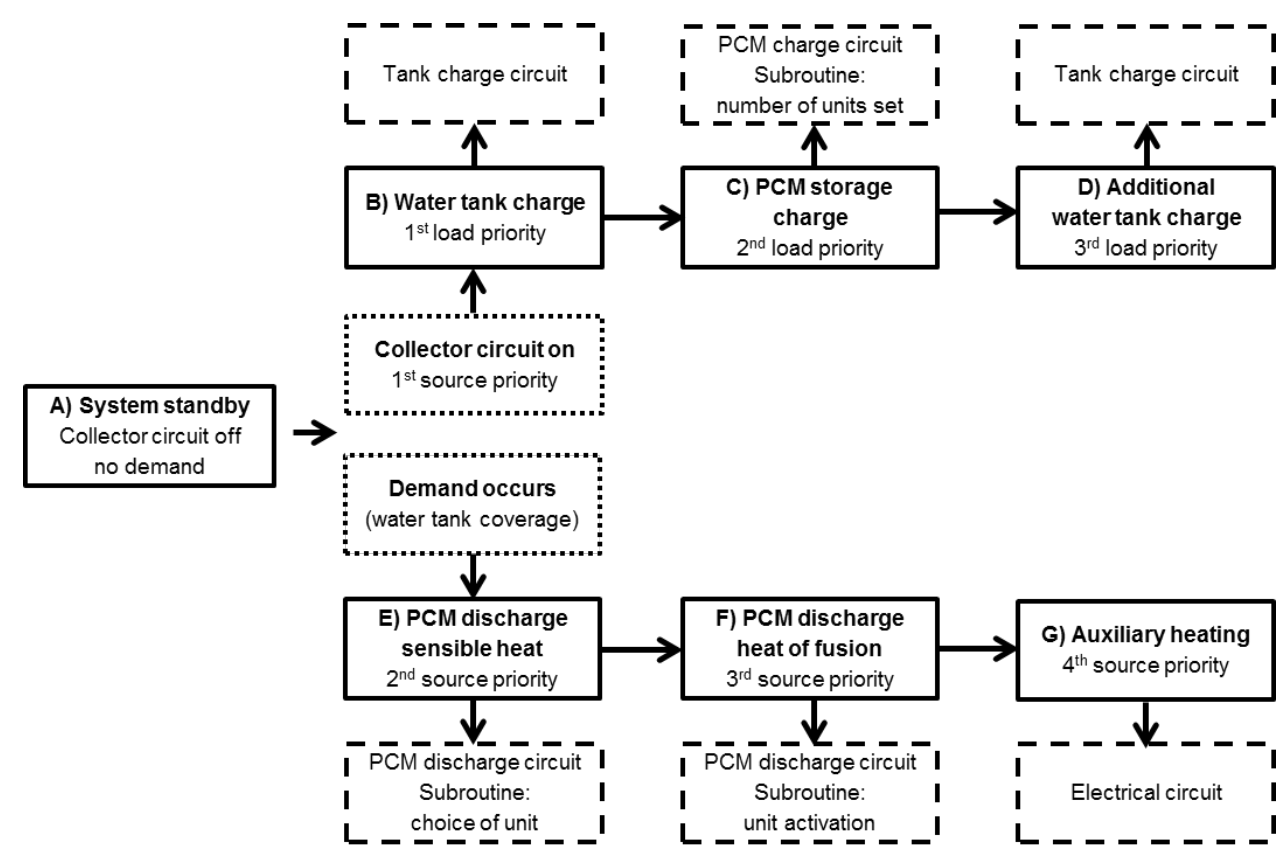

Fig. 4. Diagram of the system control strategy.

\subsection{Identified control parameter settings}

The applicability of the control strategy was confirmed with data from 4278 hours of automated control in 2016 . In 2688 of these hours, measurements were observed in mode A. Operation was set in mode B for 490 hours, in mode C for 500 hours, in mode D for 10 hours, in mode E for 190 hours, and in mode G for 400 hours. Additional water tank charging (mode D) occurred only during sunny periods in summer, while sensible heat discharging from PCM units (mode E) occurred in periods in spring, summer and autumn. Conditions for heat of fusion discharging from PCM units (mode F) were detected in spring and autumn, when sunny periods were followed by several cloudy days. However, since prototype devices for seed crystal injection were dismounted in 2016, mode F was not enabled. Thus, mode G was directly activated instead.

Threshold conditions and the final configurations of the settings for the 7 modes are presented in Table 3 . To avoid too frequent changes of mode, an observation period of five minutes was introduced before mode changes were executed. In this way, activation of auxiliary heating (mode $\mathrm{G}$ ) resulted in a minimum water tank charge of $0.25 \mathrm{kWh}$.

All valves (Fig. 3) were closed during system standby. Valves $\mathrm{X}_{1}-\mathrm{X}_{7}$ were set in three ways to enable water tank charging, PCM charging, and heat transfer from the PCM to the water tank. HTF flow through the PCM units was enabled by opening valves $\mathrm{X}_{\mathrm{PCM} 1}-\mathrm{X}_{\mathrm{PCMi}}$. 
Fluctuating collector power and limited heat transfer capacity of individual PCM units were matched by a subroutine. Starting from single unit charging, the next warmest unit was added to the PCM charging circuit when $T_{H X_{-} o u t}$ exceeded $95^{\circ} \mathrm{C}$. When $T_{H_{X} \text { out }}$ fell below $85^{\circ} \mathrm{C}$, the coldest unit was removed from the PCM charging circuit. Discharging of sensible heat (mode $\mathrm{E}$ ) and heat of fusion (mode F) were carried out depending on $T_{P C M}$, i.e. the warmest PCM unit had priority.

For auxiliary heating, the electrical resistor $\left(\mathrm{E}_{\mathrm{aux}}\right)$ was switched on by means of a relay.

Table 3. Summary of threshold conditions and mode settings.

\begin{tabular}{|c|c|c|c|c|}
\hline Operation mode & \multicolumn{3}{|c|}{ Threshold conditions } & Setting \\
\hline \multirow[b]{2}{*}{ A) System standby } & Tank temperature sufficient & $T_{B 2}$ & $>45^{\circ} \mathrm{C}$ & \multirow[b]{2}{*}{ Valves closed and pumps off } \\
\hline & $\begin{array}{c}\text { Collector temperature } \\
\text { insufficient }\end{array}$ & $T_{\text {coll }}$ & $<T_{B 1}+10 \mathrm{~K}$ & \\
\hline \multirow{2}{*}{$\begin{array}{l}\text { B) Water tank } \\
\text { charging }\end{array}$} & Tank temperature insufficient & $T_{B 2}$ & $\begin{array}{l}\leq 50^{\circ} \mathrm{C} ; \\
\text { active mode: } \\
\leq 60^{\circ} \mathrm{C}\end{array}$ & \multirow{2}{*}{$\begin{array}{c}\mathrm{X}_{2}, \mathrm{X}_{3}, \mathrm{X}_{6} \text { open } \\
\mathrm{P}_{\text {coll }}=7 \mathrm{~L} / \mathrm{min} \\
\mathrm{P}_{\text {water }}=6.3 \mathrm{~L} / \mathrm{min}\end{array}$} \\
\hline & Collector temperature sufficient & $T_{\text {coll }}$ & $\begin{array}{l}>T_{B 1}+10 \mathrm{~K} \\
\text { active mode: } \\
>T_{B 1}+2 \mathrm{~K}\end{array}$ & \\
\hline \multirow{4}{*}{$\begin{array}{l}\text { C) PCM storage } \\
\text { charging }\end{array}$} & Tank temperature sufficient & $T_{B 2}$ & $\begin{array}{l}>60^{\circ} \mathrm{C} \\
\text { active mode: } \\
>50^{\circ} \mathrm{C}\end{array}$ & \multirow{4}{*}{$\begin{array}{l}\text { Subroutine parallel charge: } \\
\text { Warmest unit priority: } X_{P C M 1}-X_{P C M} \text { set } \\
\text { If } T_{H X \text { OUT }}>95^{\circ} \mathrm{C} \text { : next warmest unit open } \\
\text { If } \bar{T}_{H X} \text { OUT }>85^{\circ} \mathrm{C} \text { : coldest unit closed } \\
\text { When } T_{P C M} \text { unit }>80^{\circ} \mathrm{C} \text { : unit closed }\end{array}$} \\
\hline & $\begin{array}{l}\text { Collector temperature sufficient } \\
\text { for PCM charge }\end{array}$ & $T_{\text {coll }}$ & $>70^{\circ} \mathrm{C}$ & \\
\hline & $\begin{array}{c}\text { Solar radiation sufficient } \\
\text { or } \\
\text { Hot collector }\end{array}$ & $\begin{array}{l}G_{\text {total }} \\
\text { or } \\
T_{\text {coll }} \\
\end{array}$ & $\begin{array}{l}>150 \mathrm{~W} / \mathrm{m}^{2} \\
\text { or } \\
T_{\text {coll }}>85^{\circ} \mathrm{C} \\
\end{array}$ & \\
\hline & Modules not fully charged & $\begin{array}{c}T_{P C M 1-} \\
T_{P C M i}\end{array}$ & $<80^{\circ} \mathrm{C}$ & \\
\hline \multirow{2}{*}{$\begin{array}{l}\text { D) Additional water } \\
\text { tank charging }\end{array}$} & Collector temperature sufficient & $T_{\text {coll }}$ & $\begin{array}{l}>T_{B 1}+10 \mathrm{~K} \\
\text { active mode: } \\
>T_{B 1}+2 \mathrm{~K}\end{array}$ & \multirow{2}{*}{$\begin{array}{c}\mathrm{X}_{2}, \mathrm{X}_{3}, \mathrm{X}_{6} \text { open } \\
\mathrm{P}_{\text {coll }}=7 \mathrm{~L} / \mathrm{min} \\
\mathrm{P}_{\text {water }}=6.3 \mathrm{~L} / \mathrm{min}\end{array}$} \\
\hline & Modules fully charged & $\begin{array}{c}T_{P C M 1-} \\
T_{P C M i}\end{array}$ & $>80^{\circ} \mathrm{C}$ & \\
\hline \multirow{3}{*}{$\begin{array}{l}\text { E) PCM discharge of } \\
\text { sensible heat }\end{array}$} & Tank temperature insufficient & $T_{B 2}$ & $<45^{\circ} \mathrm{C}$ & \multirow{3}{*}{$\begin{array}{c}\mathrm{P}_{\mathrm{PCM}}=2 \mathrm{~L} / \mathrm{min} \\
\text { Subroutine choice of unit: } \\
\text { Warmest unit priority: } \mathrm{X}_{\mathrm{PCM} 1}-\mathrm{X}_{\mathrm{PCM}} \text { set } \\
\text { When } T_{\mathrm{PCM}} \text { unit }<50{ }^{\circ} \mathrm{C} \text { : unit closed } \\
\text { Repetition with next warmest unit }\end{array}$} \\
\hline & $\begin{array}{c}\text { Collector temperature } \\
\text { insufficient }\end{array}$ & $T_{\text {coll }}$ & $<T_{B 1}+10 \mathrm{~K}$ & \\
\hline & Sensible heat in modules & $\begin{array}{l}T_{P C M 1-} \\
T_{P C M i}\end{array}$ & $>50^{\circ} \mathrm{C}$ & \\
\hline \multirow{3}{*}{$\begin{array}{l}\text { F) PCM discharge of } \\
\text { heat of fusion }\end{array}$} & Tank temperature insufficient & $T_{B 2}$ & $<45^{\circ} \mathrm{C}$ & \multirow{3}{*}{$\begin{array}{l}\text { Subroutine unit activation: } \\
\text { Warmest unit priority: } \mathrm{X}_{\mathrm{PCM} 1}-\mathrm{X}_{\mathrm{PCM}} \text { set } \\
\text { When } T_{P C M} \text { unit }<50^{\circ} \mathrm{C} \text { : unit closed } \\
\text { Repetition with next warmest unit }\end{array}$} \\
\hline & $\begin{array}{c}\text { Collector temperature } \\
\text { insufficient }\end{array}$ & $T_{\text {coll }}$ & $<T_{B 1}+10 \mathrm{~K}$ & \\
\hline & Sensible heat in modules & $\begin{array}{l}T_{P C M 1-} \\
T_{P C M i}\end{array}$ & $<50^{\circ} \mathrm{C}$ & \\
\hline \multirow{4}{*}{ G) Auxiliary heating } & Tank temperature insufficient & $T_{B 2}$ & $<45^{\circ} \mathrm{C}$ & \multirow{4}{*}{$\begin{array}{l}\text { Valves closed and pumps off } \\
\qquad E_{\text {aux }} \text { on }\end{array}$} \\
\hline & $\begin{array}{c}\text { Collector temperature } \\
\text { insufficient }\end{array}$ & $T_{\text {coll }}$ & $<T_{B 1}+10 \mathrm{~K}$ & \\
\hline & Sensible heat in modules & $\begin{array}{c}T_{P C M 1-} \\
T_{P C M i}\end{array}$ & $<50^{\circ} \mathrm{C}$ & \\
\hline & Top tank temperature below & $T_{B 3}$ & $<50^{\circ} \mathrm{C}$ & \\
\hline
\end{tabular}

\subsection{Combined charge of water tank and PCM units}

Data from $11^{\text {th }}$ April 2016, a day with clear sky, shows how mode B and mode C with its subroutines were combined for efficient storage charging. The water tank was charged for 2.5 hours and the PCM heat storage for 7.5 hours. 
Fig. 5 shows measurements of $G_{\text {total }}$ and HTF flow rates to the water tank and the PCM units over the course of the day. The sun shone on the collector array from 6:10 am to 5:00 pm. At 7:15 am, when the collector outlet temperature was high enough $\left(T_{B 3}+10 \mathrm{~K}\right)$, water tank charging started. $T_{\text {coll }}$ fell immediately, so the circulation stopped after 5 min (observation period for mode changes). From 7:30 am, the water tank was continuously charged until 9:30 am, when $T_{B 2}$ reached $60^{\circ} \mathrm{C}$ and $\mathrm{PCM}$ charging was activated. Flow rates ranged from $0.95 \mathrm{~m}^{3} / \mathrm{h}$ with one PCM unit to $1.02 \mathrm{~m}^{3} / \mathrm{h}$ when three units were being charged in parallel. PCM unit charging stopped 10 min after the collector array was shaded, and therefore the charging circuit cooled down $\left(T_{H X}<70^{\circ} \mathrm{C}\right)$.

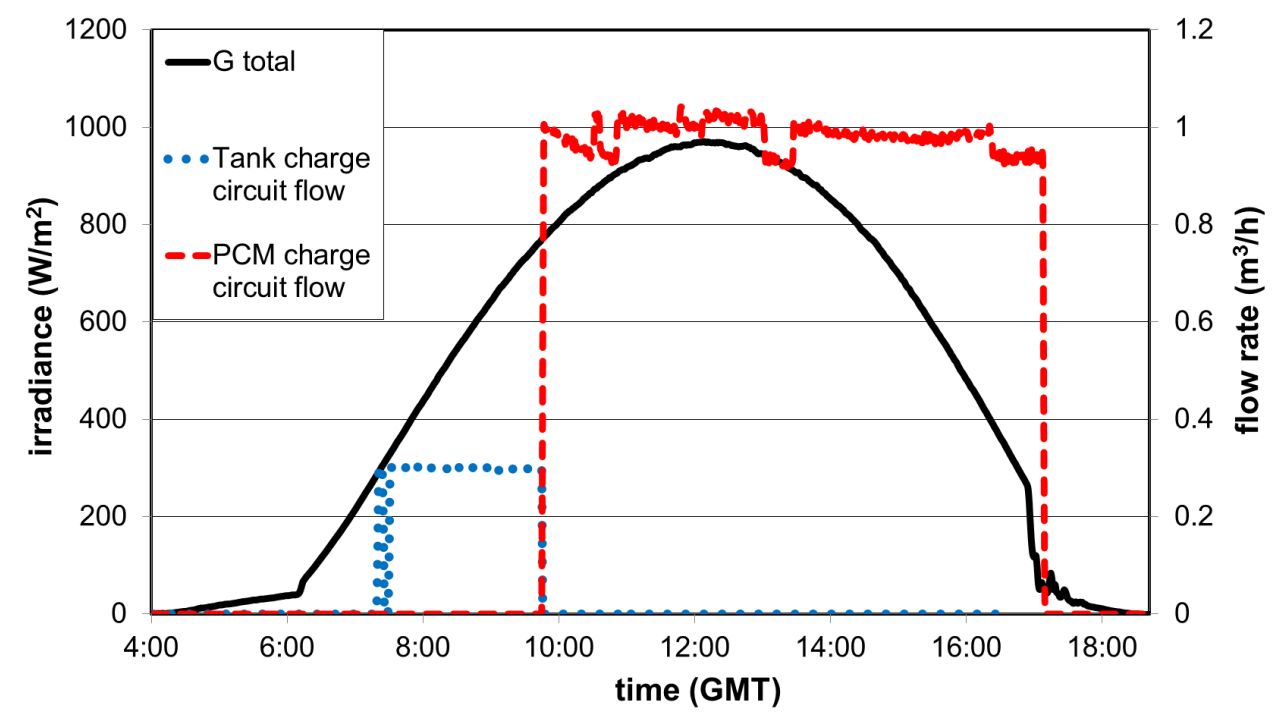

Fig. 5. Dependence of HTF flow to water tank and PCM storage on solar irradiation.

The development of $\mathrm{T}_{\text {coll }}$ depends on charging settings, as shown in Fig. 6, where periods of water tank charging are marked in blue, charging of a single PCM unit (different ones) in orange, two PCM units in red, and three PCM units in green. Initial water tank charging required a collector outlet temperature of $35^{\circ} \mathrm{C}\left(T_{B 3}=25{ }^{\circ} \mathrm{C}\right)$. After $7: 30$ am, solar irradiance was high enough to heat the HTF continuously. The water tank was sufficiently charged when $T_{\text {coll }}$ reached 65 ${ }^{\circ} \mathrm{C}$. After the circuit was stopped for $5 \mathrm{~min}, T_{\text {coll }}$ rose to $70^{\circ} \mathrm{C}$ and PCM storage charging mode started. At 10:30 am, $T_{H X}$ reached $95^{\circ} \mathrm{C}\left(T_{\text {coll }}\right.$ was at $\left.97^{\circ} \mathrm{C}\right)$ and a second PCM unit was added to the charging circuit. It was removed when $T_{H X}$ fell to $85{ }^{\circ} \mathrm{C}$. In this way the subroutine made sure that the HTF fluid temperature was high enough to achieve stable supercooling of SAT but boiling was avoided. Between 11:00 am and 4:00 pm, merely two PCM units were charged in parallel. Three PCM units were charged only between 12:50 and 1:00 pm. Units 1 and 2 reached full charge at 13:00 h, while the PCM in units 3 and 4 was partly melted at the end of the day. 


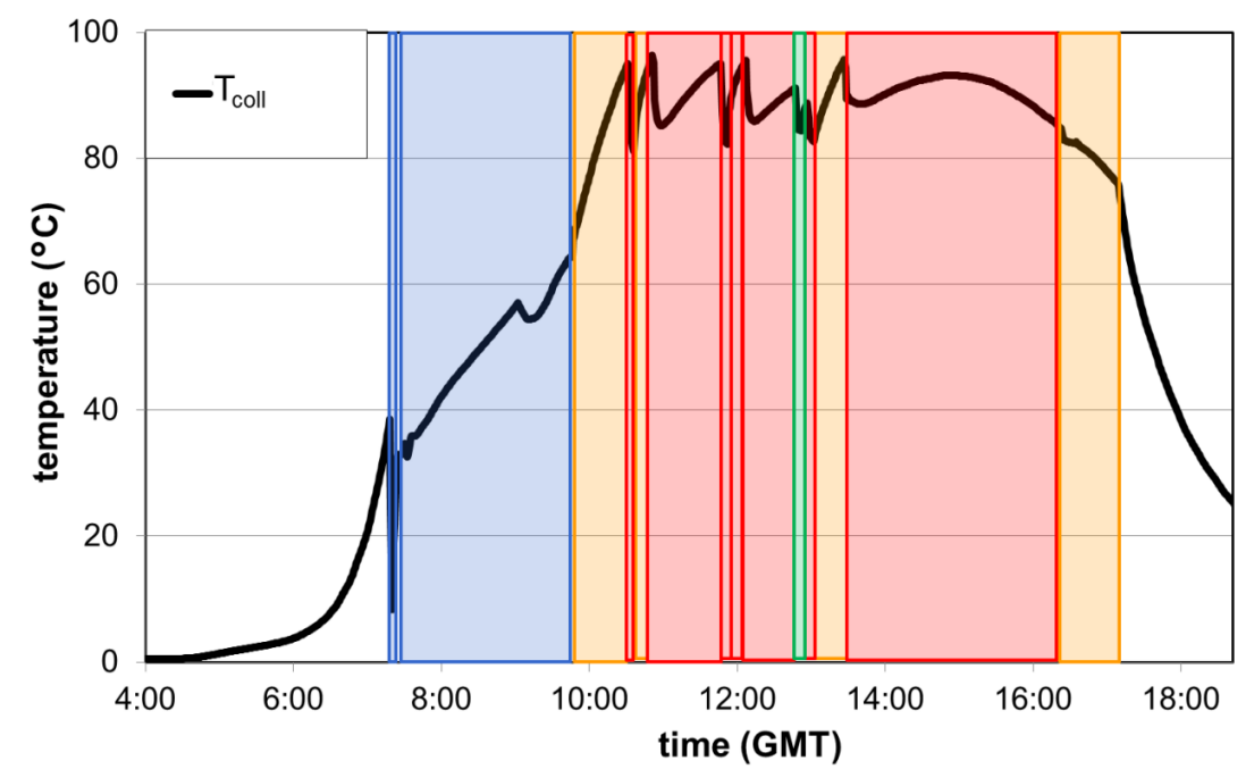

Fig. 6. Dependence of $T_{\text {coll }}$ on storage charging configuration: Blue $=$ water tank; Orange $=$ single $P C M$ unit; $\operatorname{Red}=$ two $P C M$ units; Green $=$ tree PCM units.

Fig. 7 shows the thermal power of the collector circuit (black marks), and heat transfer rates to the water tank (blue marks) and to the PCM heat storage (red marks). The collector circuit power reached peak values of up to $22 \mathrm{~kW}$ when PCM units were added to the charging circuit. The water tank was situated near the HX, so heat transfer rates to the water tank closely followed the collector circuit's thermal power. During charging of the PCM units, greater heat losses resulted due to higher HTF temperatures and longer pipework. During the course of the day, $82 \mathrm{kWh}$ of heat was transferred from the collector circuit to the heat stores: $13.5 \mathrm{kWh}$ to the water tank and $62 \mathrm{kWh}$ to the PCM storage. Pipe heat losses (from the HX to the stores) amounted to $6.5 \mathrm{kWh}$.

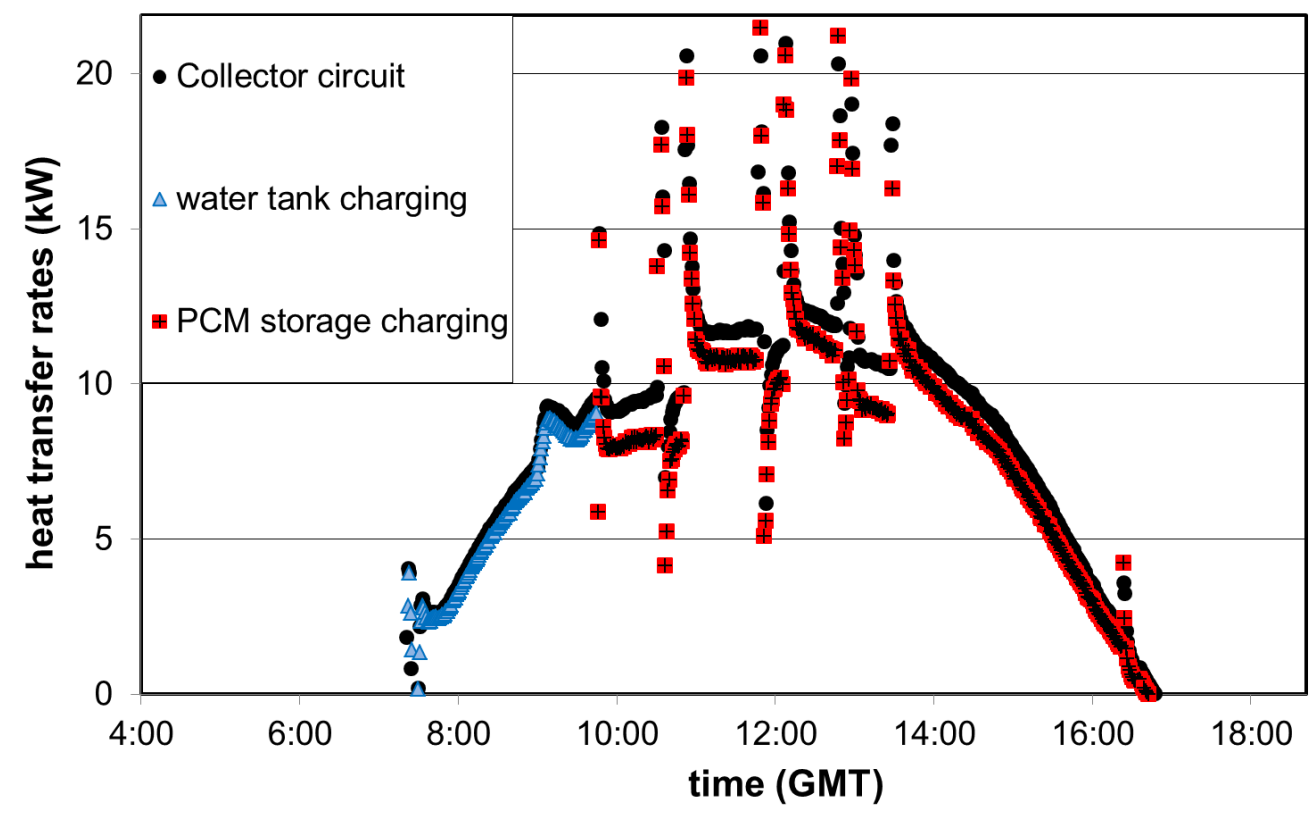

Fig. 7. Heat transfer rates during the course of a day with clear sky. 


\subsection{Short and long-term heat storage}

Fig. 8 presents a test sequence of the combined short and long-term heat storage. It shows hourly averaged values of heat transfer to/from the PCM heat storage and the $T_{P C M}$ for three units. During automated control, the units were frequently charged with solar heat. Heat transfer rates indicated that from $27^{\text {th }}$ to $30^{\text {th }}$ April, and on $5^{\text {th }}$ May, part of the stored heat was transferred to the water tank. On $1^{\text {st }}$ May, the PCM units reached full charge after noon. Over the following three days, heat losses were compensated by re-charging. Negative heat transfer rates resulted when PCM charging (mode C) was activated with $T_{P C M}>70^{\circ} \mathrm{C}$. The same situation occurred before mode $\mathrm{C}$ was deactivated as the PCM charging circuit cooled down due to decreasing collector power. The threshold values applied were chosen to avoid frequent interruption of PCM charging during partly cloudy days.

The collector array was covered from $6^{\text {th }}$ May. The three PCM units cooled down passively. The units rested for 10 , 16 and 17 days respectively before solidification of SAT was manually activated and heat of fusion (mode F) was discharged.

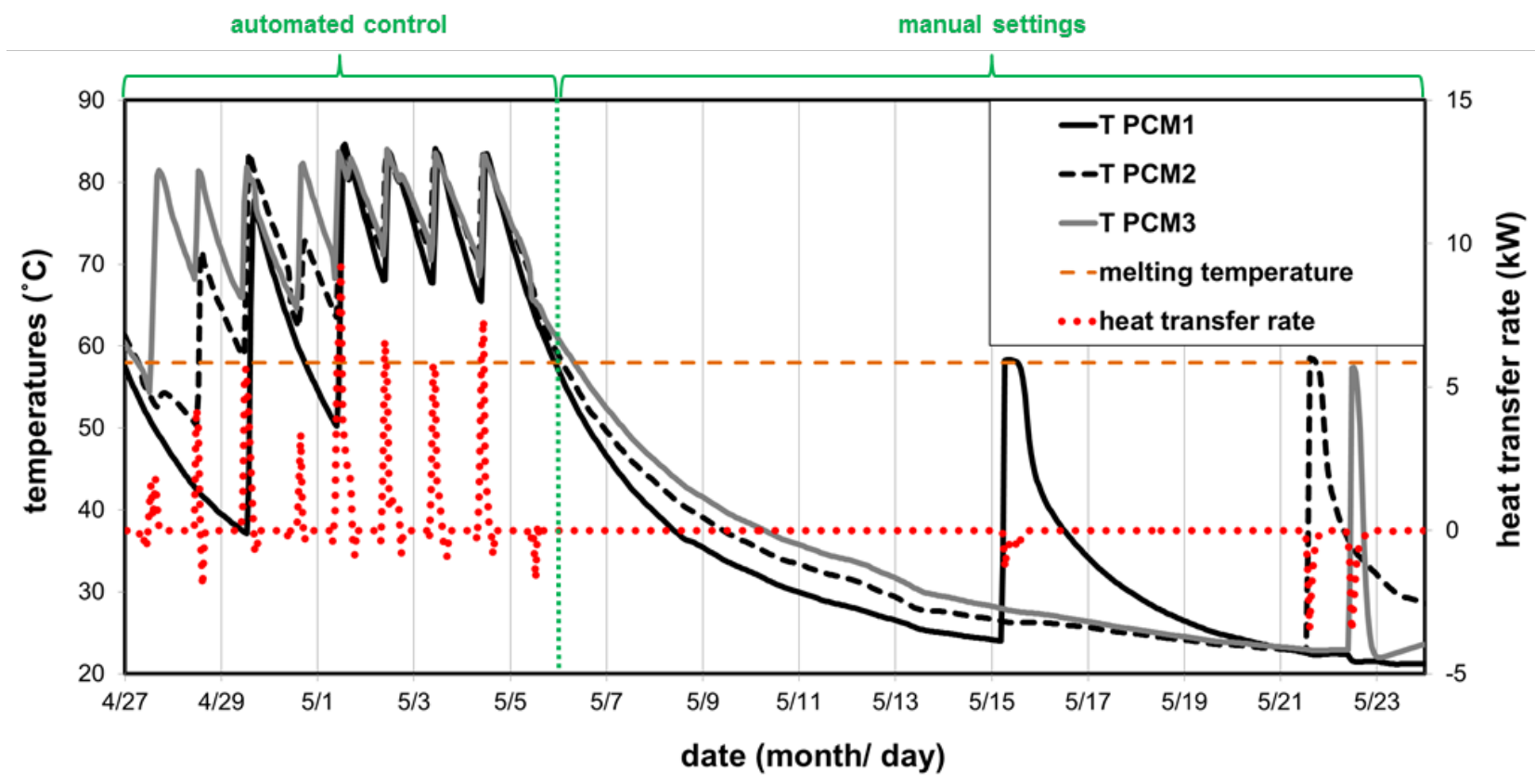

Fig. 8. PCM unit temperatures and heat transfer rates during charging and discharging in May 2016.

\subsection{System behaviour during selected periods}

Fig. 9 shows system behaviour during a sunny period of eight days in March, when five different operation modes occurred. At the beginning of the period, auxiliary heating was needed to enable DHW and SH supply. On $16^{\text {th }}$ March, $T_{B 2}$ reached $60^{\circ} \mathrm{C}$ during water tank charging, so mode $\mathrm{C}$ was activated. PCM storage charging was interrupted once by repeated water tank charging in the afternoon. During mode shifts, and when PCM units were added or removed from the PCM charging circuit, heat transfer rates of up to $36 \mathrm{~kW}$ were measured. During the following days, water tank charging was typically followed by charging of the PCM units. Mode E was activated to transfer heat from the PCM units to the water tank when the collector array could not fully cover the heat demand. On $22^{\text {nd }}$ and $23^{\text {rd }}$ March, the water tank was mainly heated in this way. 
Fig. 10 shows system behaviour in October, when only DHW was in demand. Six different operation modes occurred during a rather cloudy period of 12 days. On the $1^{\text {st }}$ and from $4^{\text {th }}$ to $8^{\text {th }}$ October, collector thermal power was sufficient to cover the demand with solar heat. Excess heat was stored in PCM units. On $5^{\text {th }}$ October, additional water storage charging (mode D) implied full PCM unit charge. From $2^{\text {nd }}$ to $4^{\text {th }}$ and from $9^{\text {th }}$ to $11^{\text {th }}$ October, DHW demand was merely covered by heat transfer from PCM units to the water tank. Interrupted flows of $2 \mathrm{~L} / \mathrm{min}$ ensured high HTF temperatures to the water tank. Heat transfer rates were below $6 \mathrm{~kW}$. On the $4^{\text {th }}$ and from $10^{\text {th }}$ October, auxiliary heating was needed to achieve hot water temperatures above $45{ }^{\circ} \mathrm{C}$. Thanks to the control strategy, the mismatch of heat supply and DHW demand was bridged for several days. It can be assumed that auxiliary heating could have been avoided during the entire period if stored heat of fusion had been used (mode F).

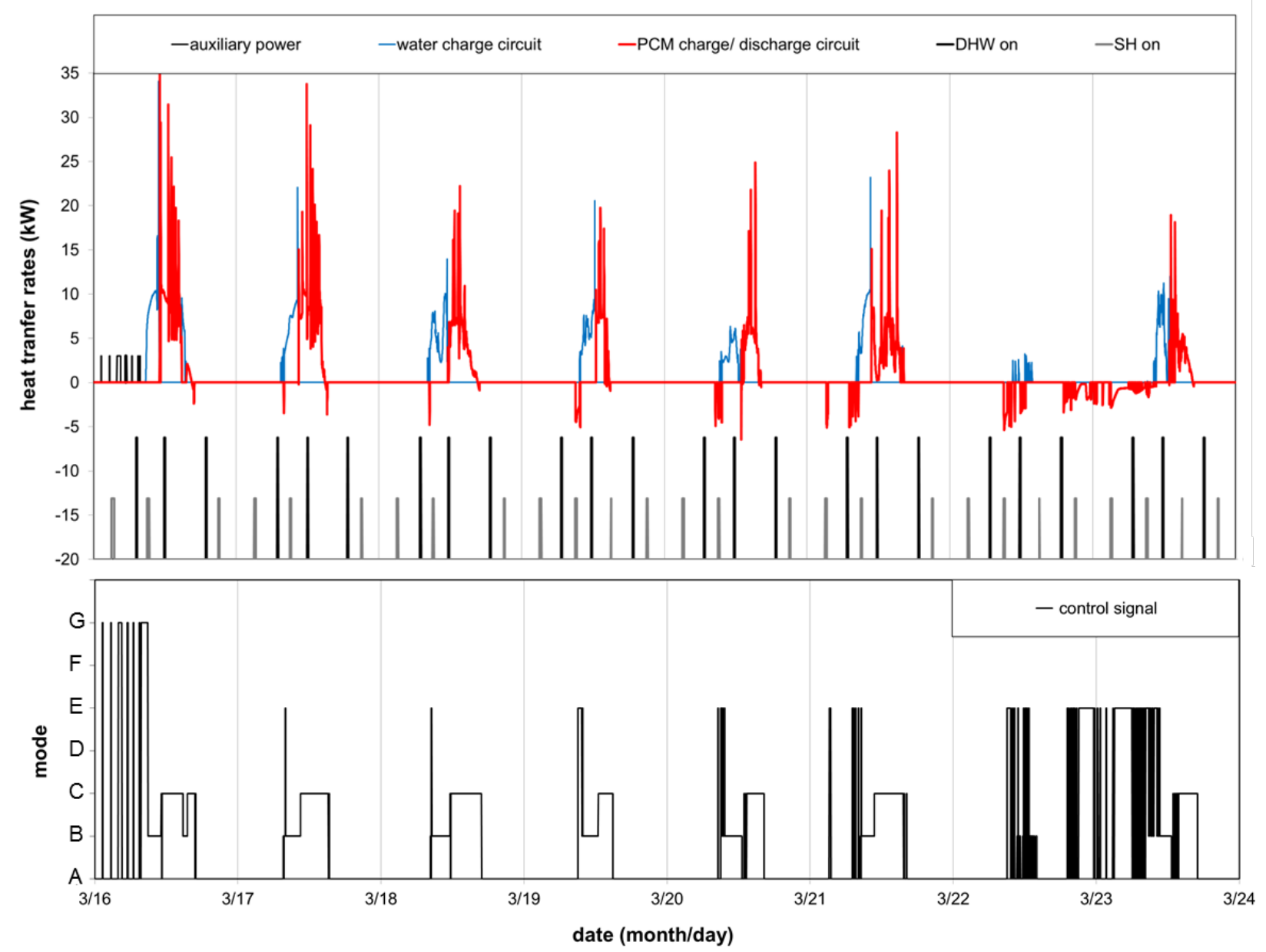

Fig. 9. Storage heat transfer, SH and DHW demand patterns, and system control signals in March 2016; Operation modes (A - G) and their settings are described in Table 3. 


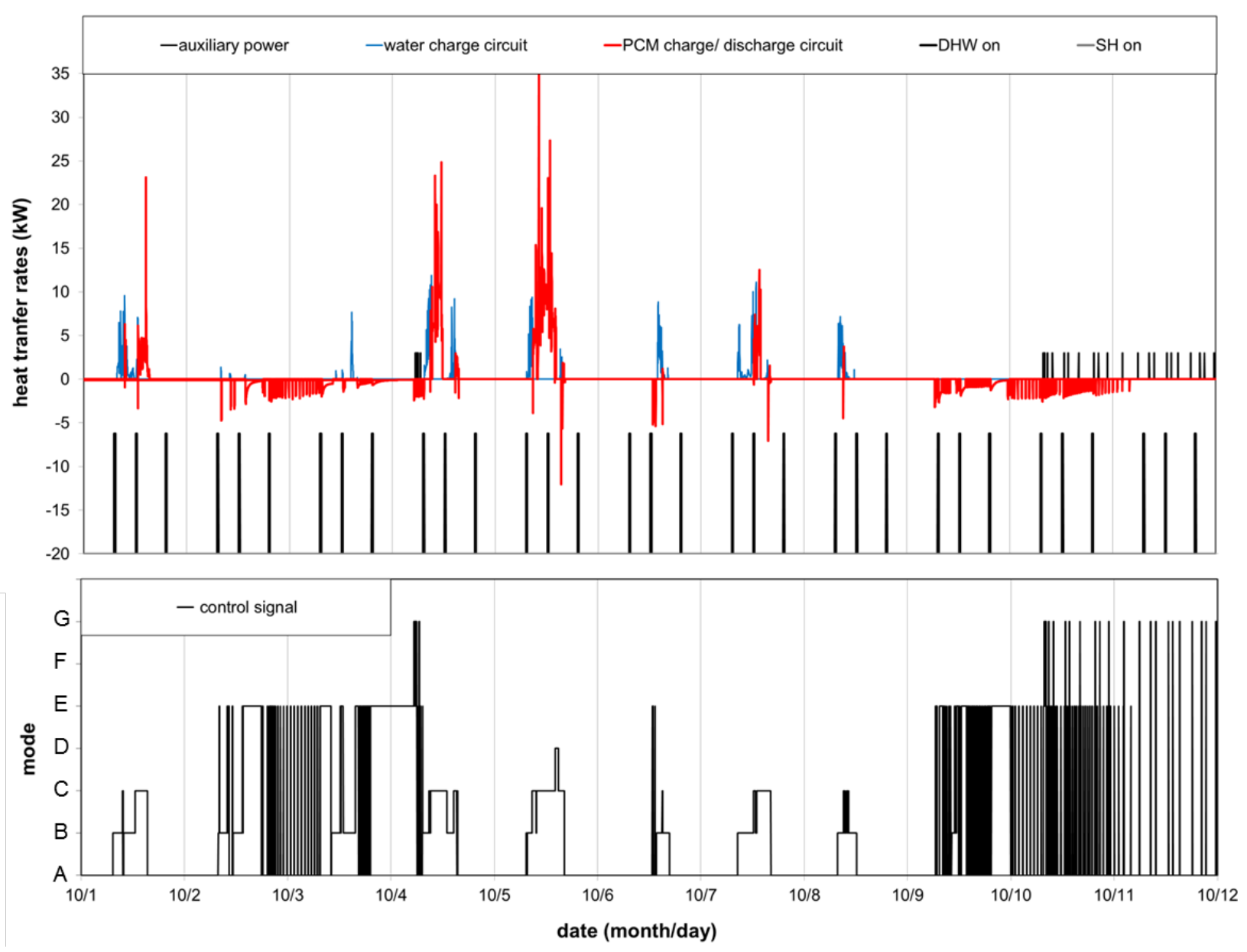

Fig. 10. Storage heat transfer, DHW demand patterns and system control signals in October 2016; Operation modes (A - G) and their settings are described in Table 3.

\section{Conclusions}

For the first time, a laboratory solar combi-system with tubular collectors and a segmented PCM heat storage prototype was successfully demonstrated in a Danish Passive House scenario. The following progress of technology development was achieved:

a) A control strategy with seven modes enabling automated system operation. With validated control parameter settings, the system worked in the following way:

- Hydraulic circuits and flow rates were set to charge first the water tank and then the PCM heat storage

- The number of PCM units was varied during charging to match their limited heat transfer capacity with the fluctuating collector power

- Additional water tank charging took place once all PCM units were fully charged

- When heat demands were not covered by the solar collectors, heat was transferred from the PCM units (the warmest first) to the water tank

- After all the PCM units were discharged below $50{ }^{\circ} \mathrm{C}$, electrical heating of the water tank ensured space heating and hot water supply. 
A mode for discharging heat of fusion on demand was included in the control strategy. Automated PCM unit activation (warmest unit priority) is followed by heat transfer to the water tank with a flow rate of $2 \mathrm{~L} / \mathrm{min}$.

b) Automated system operation showed that the PCM units, containing SAT, were frequently charged and discharged in spring and autumn. This proved that, referring to the installation space, compact PCM heat stores for combined short and long-term heat storage can be built with an effective energy storage density of $48 \mathrm{kWh} / \mathrm{m}^{3}$.

c) The applicability of the system was analysed: Heat transfer fluid temperatures closely followed the collector outlet temperature during water tank charging and were kept between 70 and $95{ }^{\circ} \mathrm{C}$ during PCM unit charging to ensure good heat transfer to the SAT composites. During continuous operation, heat transfer rates were below $16 \mathrm{~kW}$, but reached peaks up to $36 \mathrm{~kW}$ when PCM units were added to the charging circuit. A flow rate of $2 \mathrm{~L} / \mathrm{min}$ ensured high HTF temperatures when heat was transferred from PCM units to the water tank. An observation period of five minutes was proved a practical way to avoid frequent mode changes. The system prototype could be improved by shortening pipework lengths to reduce heat losses during heat storage charging and discharging. Control logic to avoid PCM units cooling during charging should be considered.

Based on this work, the full potential of the system could be explored in the future without the restrictions of the demonstrator by using simulation models and calculating the annual thermal performance of the system in a variety of application scenarios.

\section{Acknowledgements}

This research was funded by the European Commission (Grant Agreement N_295568) as part of the Seventh Framework Programme of the European Community for Research, Technological Development and Demonstration Activities under the "Collaborative Project" funding scheme through the COMTES consortium. The work was also supported by the PhD program of the Sino Danish Center for Education and Research (SDC). We thank Mark Dannemand and the DTU research technicians Troels V. Kristensen and Claus Aagaard for their practical support.

\section{References}

[1] Weiss W. (Ed.), Solar Heating Systems for Houses, a Design Handbook for Solar Combisystems, James \& James Ltd., UK, 2003.

[2] W. Streicher, R. Heimrath, C. Bales, Analysis of System Reports of Task 26 for Sensitivity of Parameters, 2003 (revised Feburary 2007). http://www.iea-shc.org/task26.

[3] E. Andersen, Solar Combi Systems, PhD thesis, Technical University of Denmark, Department of Civil Engineering report no. R-156, 2007.

[4] S. Furbo, E. Andersen, A. Thür, L.J. Shah, K.D. Andersen, Performance improvement by discharge from different levels in solar storage tanks, Sol. Energy. 79 (2005) 431-439. doi:10.1016/j.solener.2005.01.005.

[5] L.J. Shah, E. Andersen, S. Furbo, Theoretical and experimental investigations of inlet stratifiers for solar storage tanks, Appl. Therm. Eng. 25 (2005) 2086-2099. doi:10.1016/j.applthermaleng.2005.01.011.

[6] M.Y. Haller, E. Yazdanshenas, E. Andersen, C. Bales, W. Streicher, S. Furbo, A method to determine stratification efficiency of thermal energy storage processes independently from storage heat losses, Sol. Energy. 84 (2010) 997-1007. doi:10.1016/j.solener.2010.03.009. 
[7] A. Thür, S. Furbo, Compact solar Combisystem - High Efficiency by Minimizing Temperatures, Technical University of Denmark, Department of Civil Engineeing report no. R-160, 2007.

[8] L.F. Cabeza, L. Miró, E. Oró, A. de Gracia, V. Martin, A. Krönauer, C. Rathgeber, M.M. Farid, H.O. Paksoy, M. Martínez, A.I. Fernández, CO2 mitigation accounting for Thermal Energy Storage (TES) case studies, Appl. Energy. 155 (2015) 365-377. doi:10.1016/j.apenergy.2015.05.121.

[9] S. Colclough, T. McGrath, Net energy analysis of a solar combi system with Seasonal Thermal Energy Store, Appl. Energy. 147 (2015) 611-616. doi:10.1016/j.apenergy.2015.02.088.

[10] W. Kramer, A. Oliva, G. Stryi-Hipp, S. Kobelt, D. Bestenlehner, H. Drück, J. Bühl, G. Dasch, Solar-active-houses - Analysis of the building concept based on detailed measurements, Energy Procedia. 48 (2014) 895-903. doi:10.1016/j.egypro.2014.02.103.

[11] A. Oliva, G. Stryi-Hipp, S. Kobelt, D. Bestenlehner, H. Drück, G. Dasch, Solar-Active-Houses - Dynamic System Simulations to Analyze Building Concepts with High Fractions of Solar Thermal Energy, Energy Procedia. 70 (2015) 652-660. doi:10.1016/j.egypro.2015.02.173.

[12] A. Ristić, S. Furbo, C. Moser, H. Schranzhofer, A. Lazaro, M. Delgado, C. Peñalosa, L. Zalewski, G. Diarce, C. Alkan, S.N. Gunasekara, T. Haussmann, S. Gschwander, C. Rathgeber, H. Schmit, C. Barreneche, L. Cabeza, G. Ferrer, Y. Konuklu, H. Paksoy, H. Rammelberg, G. Munz, T. Herzog, J. Jänchen, E.P. del Barrio, IEA SHC Task 42 / ECES Annex 29 WG A1: Engineering and Processing of PCMs, TCMs and Sorption Materials, Energy Procedia. 91 (2016) 207-217. doi:10.1016/j.egypro.2016.06.205.

[13] B. Zettl, G. Englmair, G. Steinmaurer, Development of a revolving drum reactor for open-sorption heat storage processes, Appl. Therm. Eng. 70 (2014) 42-49. doi:10.1016/j.applthermaleng.2014.04.069.

[14] C. Reichl, D. Lager, G. Englmair, B. Zettl, M. Popovac, Fluid dynamics simulations for an open-sorption heat storage drum reactor based on thermophysical kinetics and experimental observations, Appl. Therm. Eng. 107 (2016) 994-1007.

[15] R. Köll, W. van Helden, G. Engel, W. Wagner, B. Dang, J. Jänchen, H. Kerskes, T. Badenhop, T. Herzog, An experimental investigation of a realistic-scale seasonal solar adsorption storage system for buildings, Sol. Energy. 155 (2017) 388-397. doi:10.1016/j.solener.2017.06.043.

[16] G. Engel, S. Asenbeck, R. Köll, H. Kerskes, W. Wagner, W. van Helden, Simulation of a seasonal, solar-driven sorption storage heating system, J. Energy Storage. 13 (2017) 40-47. doi:10.1016/j.est.2017.06.001.

[17] X. Daguenet-Frick, P. Gantenbein, J. Müller, B. Fumey, R. Weber, Seasonal thermochemical energy storage: Comparison of the experimental results with the modelling of the falling film tube bundle heat and mass exchanger unit, Renew. Energy. 110 (2016) 162-173. doi:10.1016/j.renene.2016.10.005.

[18] B. Fumey, R. Weber, L. Baldini, Liquid sorption heat storage - A proof of concept based on lab measurements with a novel spiral fined heat and mass exchanger design, Appl. Energy. 200 (2017) 215-225. doi:10.1016/j.apenergy.2017.05.056.

[19] S. Bonk, H. Drueck, Development and Testing of a Thermo-Chemical Energy Store - Results of a Five-Year Research Project, Proc. SWC2017/SHC2017. (2017) 1-10. doi:10.18086/swc.2017.13.01.

[20] T. Nonnen, S. Beckert, K. Gleichmann, A. Brandt, B. Unger, H. Kerskes, B. Mette, S. Bonk, T. Badenhop, F. Salg, R. Gläser, A Thermochemical Long-Term Heat Storage System Based on a Salt/Zeolite Composite, Chem. Eng. Technol. 39 (2016) 2427-2434. doi:10.1002/ceat.201600301.

[21] J. Pereira da Cunha, P. Eames, Thermal energy storage for low and medium temperature applications using phase change materials - A review, Appl. Energy. 177 (2016) 227-238. doi:10.1016/j.apenergy.2016.05.097.

[22] D. Zhou, C.Y. Zhao, Y. Tian, Review on thermal energy storage with phase change materials (PCMs) in building applications, Appl. Energy. 92 (2012) 593-605. doi:10.1016/j.apenergy.2011.08.025. 
[23] A. Sharma, V. V Tyagi, C.R. Chen, D. Buddhi, Review on thermal energy storage with phase change materials and applications, Renew. Sustain. Energy Rev. 13 (2009) 318-345. doi:10.1016/j.rser.2007.10.005.

[24] J. a. Quinnell, J.H. Davidson, Heat and mass transfer during heating of a hybrid absorption/sensible storage tank, Sol. Energy. 104 (2014) 19-28. doi:10.1016/j.solener.2013.07.035.

[25] J. Xu, R.Z. Wang, Y. Li, A review of available technologies for seasonal thermal energy storage, Sol. Energy. 103 (2013) 610-638. doi:10.1016/j.solener.2013.06.006.

[26] T. Kousksou, P. Bruel, a. Jamil, T. El Rhafiki, Y. Zeraouli, Energy storage: Applications and challenges, Sol. Energy Mater. Sol. Cells. 120 (2014) 59-80. doi:10.1016/j.solmat.2013.08.015.

[27] B. Zalba, J.M. Marín, L.F. Cabeza, H. Mehling, Review on thermal energy storage with phase change: materials, heat transfer analysis and applications, Appl. Therm. Eng. 23 (2003) 251-283.

[28] M. Dannemand, J. Dragsted, J. Fan, J.B. Johansen, W. Kong, S. Furbo, Experimental investigations on prototype heat storage units utilizing stable supercooling of sodium acetate trihydrate mixtures, Appl. Energy. 169 (2016) 72-80. doi:10.1016/j.apenergy.2016.02.038.

[29] N. Araki, M. Futamura, A. Makino, H. Shibata, Measurements of Thermophysical Properties of Sodium Acetate Hydrate, Internaltional J. Thermophys. 16 (1995) 1455-1466.

[30] M.A. Rogerson, S.S.S. Cardoso, Solidification in heat packs: I. Nucleation rate, AIChE J. 49 (2003) 505-515. doi:10.1002/aic.690490220.

[31] G. Englmair, Y. Jiang, M. Dannemand, C. Moser, H. Schranzhofer, S. Furbo, J. Fan, Crystallization by local cooling of supercooled sodium acetate trihydrate composites for long-term heat storage, Energy Build. 180 (2018) 159-171. doi:10.1016/j.enbuild.2018.09.035.

[32] G.A. Lane, Solar heat storage latent heat material Vol 1, CRC, Boca Raton, Florida, United states, 1986.

[33] J.M. Schultz, S. Furbo, Investigation of heat of fusion storage for solar low energy buildings, Proc. Sol. World Congr. 2005 Bringing Water To World, Incl. Proc. 34th Ases Annu. 3 (2005) 1833-1838.

[34] J.M. Marin, B. Zalba, L.F. Cabeza, H. Mehling, Determination of enthalpy temperature curves of phase change materials with the temperature-history method: improvement to temperature dependent properties, Meas. Sci. Technol. 14 (2003) 184-189. doi:10.1088/0957-0233/14/2/305.

[35] M. Dannemand, M. Delgado, A. Lazaro, C. Penalosa, C. Gundlach, C. Trinderup, J.B. Johansen, C. Moser, H. Schranzhofer, S. Furbo, Porosity and density measurements of sodium acetate trihydrate for thermal energy storage, Appl. Therm. Eng. 131 (2018) 707-714. doi:10.1016/j.applthermaleng.2017.12.052.

[36] H. Kimura, J. Kai, Phase change stability of sodium acetate trihydrate and its mixtures, Sol. Energy. 35 (1985) 527-534. doi:10.1016/0038-092X(85)90121-5.

[37] W. Kong, M. Dannemand, J.B. Johansen, J. Fan, J. Dragsted, G. Englmair, S. Furbo, Experimental investigations on heat content of supercooled sodium acetate trihydrate by a simple heat loss method, Sol. Energy. 139 (2016) 249-257. doi:10.1016/j.solener.2016.09.045.

[38] M. Dannemand, J.B. Johansen, S. Furbo, Solidification behavior and thermal conductivity of bulk sodium acetate trihydrate composites with thickening agents and graphite, Sol. Energy Mater. Sol. Cells. 145 (2016) 287-295. doi:10.1016/j.solmat.2015.10.038.

[39] M. Dannemand, J.B. Johansen, W. Kong, S. Furbo, Experimental investigations on cylindrical latent heat storage units with sodium acetate trihydrate composites utilizing supercooling, Appl. Energy. 177 (2016) 591601. doi:10.1016/j.apenergy.2016.05.144.

[40] J. Deng, S. Furbo, W. Kong, J. Fan, Thermal performance assessment and improvement of a solar domestic hot water tank with PCM in the mantle, Energy Build. 172 (2018) 10-21. doi:10.1016/j.enbuild.2018.04.058.

[41] G. Englmair, C. Moser, S. Furbo, M. Dannemand, J. Fan, Design and functionality of a segmented heat-storage prototype utilizing stable supercooling of sodium acetate trihydrate in a solar heating system, Appl. Energy. 221 (2018) 522-534. doi:10.1016/j.apenergy.2018.03.124.

[42] J. Dragsted, S. Furbo, M. Dannemand, F. Bava, Thermal stratification built up in hot water tank with different 
inlet stratifiers, Sol. Energy. 147 (2017) 414-425. doi:10.1016/j.solener.2017.03.008.

[43] TUV Rheinland/DIN CERTCO, Summary of EN 12975 Test Results , annex to Solar KEYMARK Certificate of Kingspan Thermomax solar collectors, 2011.

[44] G. Englmair, C. Moser, H. Schranzhofer, J. Fan, S. Furbo, A solar combi-system utilizing stable supercooling of sodium acetate trihydrate for heat storage: numerical performance investigation, Appl. Energy. 242 (2019) 1108-1120. doi:10.1016/j.apenergy.2019.03.125.

[45] C. Rathgeber, E. Lävemann, A. Hauer, Economic top-down evaluation of the costs of energy storages-A simple economic truth in two equations, J. Energy Storage. 2 (2015) 43-46. doi:10.1016/j.est.2015.06.001.

[46] International Energy Agency (IEA) Solar Heating and Cooling Program (SHC) Task 54 on Price Reduction of Solar Thermal Systems, "Infor Sheets" [Online]. Available: http://task54.iea-shc.org/info-sheets [Accessed:15Oct-2019].

[47] S. Furbo, V. Korsgaard, Varmelagring til solvarmenalæg, Technical University of Denmark, Thermal Insulation Laboratory report no. 162, 1984.

[48] Passive House Institute, "Passive House Institute.” [Online]. Available: https://passivehouse.com. [Accessed: 31-Oct-2018].

[49] DS 439, Norm for vandinstallationer - Code of Practice for domestic water supply, Danish Standards (2009) 75. 